\title{
BRONCHOSCOPY WITH THE AID OF DIAZEPAM
}

\author{
A. M. Straja, M.D., D. D. Munro, M.D., AND \\ R. G. B. GLLBERT, M.B., F.R.C.P.(C), F.F.A.R.C.S. ${ }^{*}$
}

IN THE "PACKAGE INSERT" given for the use of intravenous diazepam, it is stated that this drug should not be used for endoscopy. The purpose of this brief submission is to refute this statement by reporting 77 consecutive cases in which it was given to advantage in cases of bronchoscopy. This study supports that of Rogers, Waterman, Domm, and Sunay. ${ }^{1}$

\section{INTRODUCTION}

Bronchography will furnish more valid results when it is preceded by bronchoscopy and by bronchial aspiration, particularly when there are abundant secretions in the tracheobronchial tree. Bronchoscopic aspiration of secretions facilitates complete filling of all the segmental and smaller bronchial branches with the contrast medium. The most valuable information is gained from bronchoscopy when there is good anaesthesia. It is our opinion that topical anaesthesia is to be preferred in the majority of cases ${ }^{2}$ and we will briefly review the reasons for this preference.

Respiratory movements of the bronchial tree are passive in character and reflect changes in the elastic pulmonary tissue coincident with movements of the diaphragm and chest wall. These movements produce a corresponding alteration in the intrathoracic pressure. The lobar bronchi and segmental branches lengthen with each inspiration and shorten with each expiration. The upward and downward excursion of the carina is more limited.

With inspiration the calibre of the larger bronchi increases, reflecting a decrease in intrathoracic pressure, and with expiration the calibre of the lumen decreases. Frequently, toward the end of expiration, the relatively short, unsupported posterior wall of the lower trachea and the lower bronchi bulges forward. This phenomenon will be greatly increased in the presence of pulmonary emphysema and bronchial asthma, in which the expiratory intrathoracic pressure is high. The changes in calibre of the bronchial lumen are a part of the mechanism of the usual type of obstructive emphysema. Under these conditions it is well to preserve the mechanism of normal bronchial drainage as far as possible. Specifically, this mechanism consists of (a) the "tussive squeeze," an expiratory phenomenon occurring in the smaller peripheral bronchial branches which tends to propel secretions upward; $(b)$ the ciliary action, with the same objective; $(c)$ the "tussive blast," the cough, which clears secretions from larger bronchi, the trachea, and the larynx.

'Dr. Straja is a resident in anaesthesia, Dr. Munro is chief of surgery, and Dr. Gilbert is chief of anaesthesia, Royal Edward Chest Hospital, Montreal. 
It is clear that maintenance of the cough reflex will be of advantage in the treatment of atelectasis and retained secretions, as secretions are thereby brought within reach of the suction tube. Since general anaesthesia interferes with the motility of the tracheobronchial tree and consequently with the possibility of good functional appreciation, we consider topical anaesthesia to be the undoubted choice in most cases. Following recent haemoptysis in cases of tuberculous cavitation, in cases of malignant diseases, in instances where there are copious secretions, or in lung abscess, we therefore strongly recommend the use of topical anaesthesia. If a biopsy is taken under topical anaesthesia, blood can be immediately coughed up.

There are special indications for the use of general anaesthesia in both adults and children; for example, when foreign bodies are to be removed or when more complete relaxation is required, as in patients with short or muscular necks or prominent upper teeth, general anaesthesia may be indicated. It may also be helpful at other times when it is unnecessary to assess bronchial tree motility or when presence of the cough reflex is not required. ${ }^{2}$

\section{Premedicatron}

Adequate premedication and topical anaesthesia contribute much to the safety and efficiency of the procedure and the comfort of the patient. An unsatisfactory bronchoscopy is more likely to be due to poor preparation of the patient than to the technique. Premedication depends upon the patient's age, physical status, and possible associated pathology, such as pulmonary emphysema or asthma. Premedication aimed at complete drying of secretions should be avoided because this can destroy the opportunity of seeing from whence the secretions are coming, and can make it more difficult to obtain specimens for bacteriological, cytological, and histo-pathological study.

When patients have to undergo bronchography, they need adequate premedication and topical anaesthesia but they should not be so sedated that they may be unable to co-operate. Ideally premedication should diminish but preserve the cough reflex, ${ }^{1}$ allay the patient's anxiety so as to permit him to relax and cooperate, cause minimal interference with the bronchial dynamics and with the secretions, interfere as little as possible with the cardiovascular and autonomic nervous systems, and produce some degree of amnesia.

\section{DiAzePAM $^{3-6}$}

Diazepam is a benzodiazepine derivative with the chemical formula 7-chloro1,3-dihydro-1-methyl-5-phenyl-2H-1,4-benzodiazepine-2-one. It is a tranquillizer. It seems to effect no depression, stimulation, or exaggeration of the cough reflex. Intravenous administration of this drug forms a part of current European practice and during the past few years has been investigated in North America. The drug has been found to be a useful agent for the induction of anaesthesia.

In the opinion of most investigators, patients premedicated with diazepam intravenously come to surgery relaxed, calm, co-operative and without signs of 
cardiovascular or autonomic disturbance, and there is little or no recall of the procedure. It is held to be a good agent for induction that could replace thiopentone if need be (e.g. in porphyria)..$^{3}$ There is little alteration in respiratory rate, heart rate, or blood pressure, and there are no accompanying vagal effects such as coughing, laryngospasm, hiccup, or hypersecretion. Neither salivary secretions nor bronchial secretions are stimulated, even in the absence of vagolytic premedication.

\section{OBjectives}

The objectives of this investigation have been $(a)$ to discover if diazepam, given intravenously immediately prior to bronchoscopy, is of value for the patient and for the bronchoscopist, $(b)$ to ascertain the dosage of the drug, $(c)$ to see if, with its use, classical premedication may be reduced, $(d)$ to observe patients receiving this drug and determine if they are more calm and relaxed than others, (e) to judge whether advantage may be taken of a more "anaesthetized" patient for teaching purposes.

\section{Method}

To evaluate diazepam, a special form was designed to note all relevant information. The vital signs, degree of co-operation, anxiety, relaxation, and level of consciousness were noted prior to and immediately after the administration of diazepam, during the procedure, at its termination, and one hour later. On the same sheet, information concerning the bronchoscopic procedure, as well as failures or side-effects, if any, were also noted. The patients were questioned the next day about their recollections of the procedure. This investigation was carried out in both a thoracic hospital and a neurological hospital, and included patients who presented widely differing pathologies, both acute and chronic.

Those who were premedicated received meperidine, pentobarbital, and atropine, or meperidine and atropine, or pentobarbital and atropine, the dosage depending upon age, weight, physical status, and pathology. Certain patients were not premedicated, and the procedure was performed after diazepam had been administered intravenously.

Topical anaesthesia was produced with Xylocaine 4 per cent administered in the form of aerosol and completed with intratracheal instillation. Diazepam was slowly injected intravenously, at a rate of $5 \mathrm{mg} / \mathrm{min}$, in such a manner that the full dosage was given approximately 60 to 90 seconds before the introduction of the bronchoscope.

\section{Results}

The results are presented in Tables I to XI. The administration of diazepam diminished the dosage requirement of the premedicant drugs. Diazepam reduced anxiety, induced co-operation, and increased relaxation. In this way the procedure was made easier both for the patient and for the surgeon. From a practical point of view, diazepam had insignificant effects upon the autonomic nervous system and the cardiovascular and respiratory systems. It did not interfere with the 
TABLE I

\begin{tabular}{ll}
\hline \hline Procedures & 77 \\
Sex & \\
$\quad$ male & 58 \\
$\quad$ female & 19 \\
Age & \\
$\quad$ average & 51.23 \\
$\quad$ range & $18-81$ \\
Physical status & \\
$\quad$ good & 22 \\
$\quad$ fair & 34 \\
$\quad$ poor & 18 \\
$\quad$ critical & 5 \\
Average weight $(\mathrm{kg})$ & 59.81 \\
\hline
\end{tabular}

TABLE II

\begin{tabular}{lr}
\hline \hline Pathology for which procedures \\
have been given \\
br. carcinoma & 30 \\
tuberculosis & 17 \\
atelectasis & 4 \\
haemoptysis & 77 \\
retention of bronchial secretions & 2 \\
histoplasmosis and paragonimiasis & 3 \\
other pulmonary diseases & 14 \\
Associated pathology presented by & \\
these patients & \\
impaired respiratory function & 15 \\
cardiovascular diseases & 9 \\
asthma & 1 \\
tuberculosis & 5 \\
histoplasmosis & 1 \\
anxiety reaction & 3 \\
chronic bronchitis & 12 \\
neurological disorders & 6 \\
emphysema & 4 \\
alcoholism & 6 \\
diabetes & 2 \\
\hline
\end{tabular}

TABLE III

\begin{tabular}{lc}
\hline Procedures & 77 \\
Average duration (min) & 20.8 \\
range (min) & $5-55$ \\
Elective procedures & 71 \\
Diagnostic procedures & 72 \\
Emergency procedures & 6 \\
Therapeutic procedures & 5 \\
Biopsy & 11 \\
Bronchography & 10 \\
(no patient was too drowsy for & \\
the bronchography) & \\
\hline
\end{tabular}

secretory function and the motility of the tracheobronchial tree, nor did it interfere with the cough reflex or increase the risk of laryngospasm or bronchospasm. ${ }^{\text {? }}$

In the absence of good local anaesthesia, with or without diazepam, the procedure is difficult and can induce laryngospasm or bronchospasm. Diazepam has the advantage of producing amnesia in a number of patients. It is practically devoid of side-effects, when used intravenously in recommended dosage.

The mean dosage of diazepam recommended by us for the intravenous injection before the procedure is $0.15 \mathrm{mg} / \mathrm{kg}$ body weight, administered slowly at a rate not more than $5 \mathrm{mg} / \mathrm{min}$. It was impossible in this series to predict which patients might deviate for the average responses. 


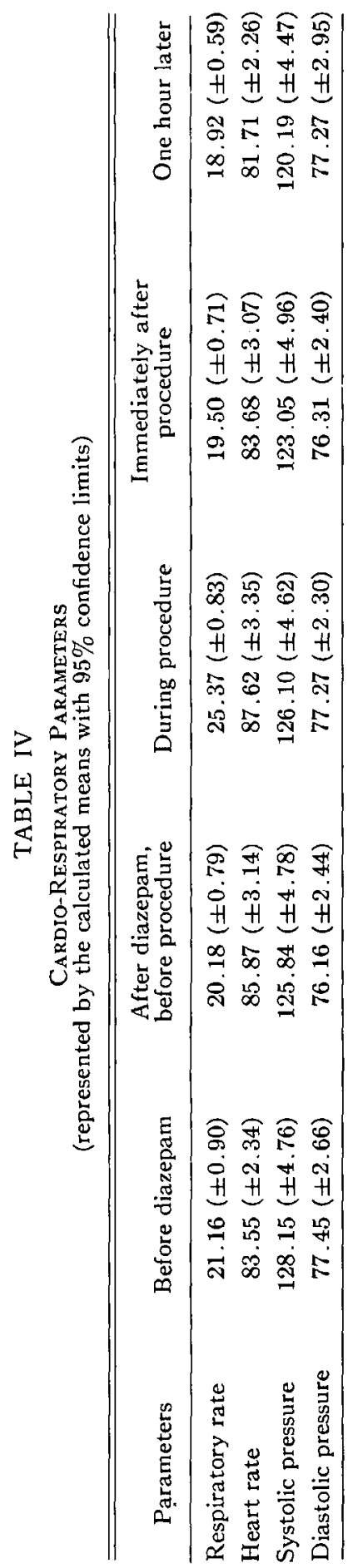


TABLE V

Co-oreration

\begin{tabular}{|c|c|c|c|c|c|}
\hline & None & Slight & Fair & Good & Complete \\
\hline Before diazepam & 10 & 5 & 22 & 23 & 17 \\
\hline $\begin{array}{l}\text { Immediately after diazepam, } \\
\text { before procedure }\end{array}$ & - & - & 7 & 42 & 28 \\
\hline During procedure & 2 & - & 8 & 41 & 26 \\
\hline After procedure & 1 & - & 4 & 38 & 34 \\
\hline One hour later & - & 7 & 3 & 33 & 34 \\
\hline
\end{tabular}

TABLE VI

RELAXATION

\begin{tabular}{lccccc}
\hline & None & Slight & Fair & Good & Complete \\
\hline Before diazepam & 9 & 18 & 33 & 14 & 3 \\
Immediately after diazepam, & & & & & \\
$\quad$ before procedure & - & 2 & 8 & 51 & 16 \\
During procedure & 3 & 3 & 7 & 48 & 16 \\
After procedure & 1 & - & 7 & 48 & 21 \\
One hour later & 1 & 5 & 7 & 32 & 32 \\
\hline
\end{tabular}

TABLE VII

ANXIETY

\begin{tabular}{lccccc}
\hline & None & Mild & Moderate & Marked & Severe \\
\hline Before diazepam & 2 & 31 & 31 & 14 & 9 \\
$\begin{array}{l}\text { Immediately after diazepam } \\
\quad \text { before procedure }\end{array}$ & 37 & 29 & 10 & 1 & - \\
During procedure & 51 & 16 & 9 & - & 1 \\
After procedure & 60 & 11 & 5 & - & 1 \\
One hour later & 54 & 19 & 3 & - & 1 \\
\hline
\end{tabular}

TABLE VIII

Level of Consciousness

\begin{tabular}{lccccc}
\hline & $\begin{array}{c}\text { Awake, } \\
\text { alert }\end{array}$ & $\begin{array}{c}\text { Awake, } \\
\text { drowsy }\end{array}$ & $\begin{array}{c}\text { Easily } \\
\text { aroused }\end{array}$ & $\begin{array}{c}\text { Difficult } \\
\text { to arouse }\end{array}$ & $\begin{array}{c}\text { Cannot } \\
\text { arouse* }\end{array}$ \\
\hline $\begin{array}{l}\text { Before diazepam } \\
\text { Immediately after diazepam, } \\
\text { before procedure }\end{array}$ & 58 & 18 & - & - & 1 \\
$\begin{array}{l}\text { During procedure } \\
\text { After procedure }\end{array}$ & 18 & 39 & 17 & 2 & 1 \\
One hour later & 5 & 40 & 29 & 2 & 1 \\
\hline
\end{tabular}

*Patient in coma: level of consciousness not related to diazepam, but to the neurological disorders. 
TABLE IX

Amnesia for the Procedure

\begin{tabular}{lr}
\hline No recall & 20 \\
Slight recall & 29 \\
Moderate recall & 23 \\
Total recall & 5 \\
\hline
\end{tabular}

TABLE $\mathrm{X}$

\begin{tabular}{ll}
\hline \hline Spasm & none \\
Adverse effects & none \\
\hline
\end{tabular}

TABLE XI

Evaluation of the Procedure

\begin{tabular}{lcc}
\hline & $\begin{array}{c}\text { Anaesthetist's } \\
\text { point of view }\end{array}$ & $\begin{array}{c}\text { Surgeon's } \\
\text { point of view }\end{array}$ \\
\hline Excellent & 21 & 23 \\
Good & 43 & 39 \\
Fair & 7 & 8 \\
Poor & 6 & 7 \\
\hline
\end{tabular}

With regard to the cases considered fair or poor, 12 had inadequate local anaesthesia, 3 had insufficient diazepam. In addition, in three patients the premedication dosage was inadequate: in four patients too little time had elapsed between the premedication and the procedure; in two patients the premedication was adninistered too far in advance of the procedure.

\section{RÉSUMÉ}

En administrant du diazépam, on peut diminuer le dosage de la prémédication. Le diazépam diminue l'anxiété, favorise la co-opération du malade et augmente le relâchement. De cette façon, l'intervention devient plus facile et pour le malade et pour le chirurgien.

A toute fin pratique, le diazépam n'a que très peu d'effet sur le système nerveux autonome et sur les systèmes cardiovasculaire et respiratoire. Le diazépam n’a pas dérangé la fonction secrétoire et la motilité de l'arbre trachéo-bronchique. De même, il n'amoindrit pas le réflexe de la toux et il n'augmente pas le risque de laryngospasme ou de bronchospasme.

Si lon ne pratique pas une bonne anesthésie locale, avec ou sans diazépam, la bronchoscopie est difficile et elle peut provoquer un laryngospasme ou un bronchospasme. Le diazépam a l'avantage de produire l'amnésie chez un certain nombre des malades. Quand il est employé à bon escient par voie veineuse, il ne produit pratiquement pas d'effets secondaires.

La dose moyenne de diazépam que nous préconisons en injection intraveineuse avant l'intervention est de $0.15 \mathrm{mg} / \mathrm{kg}$ de poids, administré lentement à la vitesse d'au plus $5 \mathrm{mg} / \mathrm{min}$. Dans cette série, il a été impossible de prévoir quels sujets ne répondraient pas comme la moyenne des malades à ce médicament.

\section{ACKNOWLEDGMENTS}

We wish to thank the Hoffman-La Roche Company, especially Mr. Harald J. Wehner, Director of the Medical Services, for supplying diazepam (Valium) for this study.

\section{REFERENCES}

1. Rocers, W. K.; Waterman, D.; Domm, Sheldon; \& Sunay, A. Efficacy of a New Psychotropic Drug in Bronchoscopy. Dis. Chest. 47: 280 (1965).

2. Procton, F. Donald. Anaesthesia for Peroral Endoscopy and Bronchography. Anesthesiology. 29: 1025 (1968). 
3. Beaulieu, D.; Goyette, M.; \& KeÉru-SzÁNtó, M. Anaesthetic Time-dose Curves: Experiences with Diazepam. Canad. Anaesth. Soc. J. 14: 326 (1967).

4. Boucquemont, J. G. Essais cliniques du R 05-2807 ou diazépam en anesthésiologie. Thèse. Faculté de médecine de Lyon, France (1964).

5. Campan, L. \& Espagno, M. Th. Notes sur le diazépam en anesthésiologie. Ann. anesth. franc. 4: 711 (1964).

6. McCuish, ANDré. Diazepam as an Intravenous Induction Agent for General Anaesthesia. Canad. Anaesth. Soc. J. 13: 562 (1966).

7. Fox, G. S.; Wynands, J. E.; \& BhambHani, M. A Clinical Comparison of Diazepam and Thiopentone as Induction Agents to General Anaesthesia. Canad. Anaesth. Soc. J. 15: 281 (1968). 